\title{
The Status of Children Born Out of Wedlock in Indonesian Context with Special Reference to Their Inheritance Right Perspective of Maqasid Al- Shariah
}

\author{
Zaenul Mahmudi \\ Department of Al-Ahwal Al-Syakhshiyyah \\ Postgraduate of Universitas Islam Negeri Maulana Malik Ibrahim Malang, Indonesia \\ Email: zenmahmudi@as.uin-malang.ac.id
}

\begin{abstract}
The discourse on the right of children born out of wedlock, especially concerning their rights towards their biological fathers is a hot topic triggering heat debate among scholars. Orthodox Muslim scholars had unanimous opinion denying their lineage towards their fathers while human right activists contended that they should enjoy the same benefits as those of children born of the wedlock. They based their opinion on the Universal Declaration of Human Rights and the United Nations Convention on the Right of Child. This paper focuses on the examination of the Constitutional Court decree Number: 46/PUU-VIII/2010 concerning with legal status of children born out of wedlock. The study will delve into the reasons behind the decree and analyze them according to Islamic law, especially by the objectives of sharia (maqasid al-shariah). The maqasid al-shariah assumes that Islamic law is a linked system consisting of multi-dimensions aspects strengthening each other. Therefore, based on maqasid al-shariah, the examination of children born out of wedlock should regard international, national as well as Islamic law. The examination also regards various aspects for instances: justice, welfare, psychology, and social status of the children and their mothers. These multi-dimensions of life were employed in issuing the legal decree concerning with the children born out of wedlock. The results from this study show that first, the reason behind orthodox $s$ of Islamic law not to associate the lineage of children born out of wedlock towards their biological father is that they lacked evidence as those of their mothers such as pregnancy, birthing, and suckling. Second, based on the constitutional decree, the lineage of children born out of wedlock should be established toward their father, and the children should enjoy the rights towards their fathers to the extent that the legitimate children did. They also have the right of inheritance towards not only their mothers but also their biological fathers as well as their parents' families.
\end{abstract}

Keywords — inheritance; children born out of wedlock; constitutional court; maqasid al-shariah

\section{INTRODUCTION}

Children are the most vulnerable persons to be deprived of their rights. However, this vulnerability should not make them as merely the object of care [1]. Even though they are weak as they have no legal capacity to sue their rights, they are perfect human since the care for them should be structured to avoid their freedom. The vulnerability of the children stimulated the leading international intergovernmental organizations to structure and stipulate legal treaties to protect them. Among the legal treaties were The Universal Declaration of Human Right (UDHR), The Declaration of the Rights of the Child (1924), The United Nations Declaration of The Rights of the Child (1959), and the United Nations Convention on the Rights of the Child (1989) (CRC).[2]

CRC was the result of the session of UN General Assembly on November 20, 1989. The CRC was signed by Indonesian Government on January 26, 1990, in New York and ratified in the form of Presidential Decree number 36/1990. Indonesian Government also issued the law number 23/2002 concerning with the child protection that was amended with the law number 35/2014. The amendment to the law was performed to accommodate the protection of the children with the social change. Besides, the amendment showed the serious attention of the
Indonesian government towards the case. There are abundant regulations to defend the children's right adopted by the government. However, the regulations are useless unless supported by strong desires of the community to protect them.[3] On the other hand, giving too much power to the state in the protection can undermine the power of the parents to care for their children.[4, p. 114] Therefore, the protection of the children by the state should not ignore the role of their parents, communities, and families.[5]

Islamic law also gives much attention to the protection of the children, especially concerning the orphan. There are many Quranic verses prescribing Muslims to protect the orphaned children, for instance, the Muslims prescribed to doing goodness (al-Baqarah: 83), giving wealth (al-Baqarah: 177, 215); improvement (alBaqarah: 220), giving their properties (al-Nisa': 2), dealing justly (al-Nisa': 3), and educating them (al-Nisa': 6).

The provisions of the Quran to protect the children are not only limited to the legitimate but also the illegitimate children born out of wedlock. The protection of the children should be mainstreamed as their relationship towards their biological fathers tended to fade away. The children prefer having their both parents than only mother or mother and stepfather.[6]

Indonesia as the most populous Muslim countries and the member of UN that ratified the UDHR and CRC is 
an interesting place to be studied concerning with the protection of the children born out of wedlock, especially with their rights of inheritance. This article deals and examines their legal status and rights of inheritance to their biological fathers in the Indonesian context.

\section{RESEARCH METHOD}

This study that concerns the legal status of children born out of wedlock employs conceptual as well as statute approaches. The first means that the writer should define the concept of children born out of wedlock, especially that was given by Indonesian laws. The approach also examines its definition given by orthodox Muslim jurists. The second approach examines the decree of the Constitutional Court of Indonesia number 46/PUUVIII/2010 concerning the children born out of wedlock as to the extent, the decree covers. The two approaches are employed to give the best interest for the children born out of wedlock, especially the illegitimate children by the objectives of sharia (maqasid al-shariah) concerning their status in Islamic law of inheritance.

\section{RESULT AND DISCUSSION}

\section{A. Status of Children Born out of Wedlock Based on the Indonesian Constitutional Court (ICC) Decree No. 46/PUU-VIII/2010}

Regarding the status of the children born out of wedlock, the UDHR declared the importance of protecting the rights of the children, whether they are born in or out of wedlock as article 25 (2) said:

"Motherhood and childhood are entitled to special care and assistance. All children, whether born in or out of wedlock, shall enjoy the same social protection." [7]

The state parties, according to the declaration should not differentiate the rights of the children born in and out of wedlock. The children also have the right to the identity of their families as stipulated in the UNCRC article 8 as follows:

"1. States Parties undertake to respect the right of the child to preserve his or her identity, including nationality, name and family relations as recognized by law without unlawful interference.

2. Where a child is illegally deprived of some or all of the elements of his or her identity, States Parties shall provide appropriate assistance and protection, with a view to reestablishing speedily his or her identity". [8]

The regulations concerning the children born out of wedlock as was stipulated by the international treaties should be exerted by state parties. The treatment for the children born out of wedlock, however, varies among Muslim countries. Jordan, for instance, obliges their relatives to support maintenance for the children. In Egypt, the support of maintenance of the children was asserted by the government. While in Tunisia, besides the children enjoyed the maintenance from their relatives, the government also demanded their biological fathers to give maintenance payments.[9] The differences in the treatment for the children in the Muslim countries were influenced by Muslim jurists.
The concept of children born out of wedlock in Indonesian should regard the law Number 1/1974 concerning with marriage as article 2 said:

"(1) The marriage is sound if performed according to the laws of their religions and faiths, (2) Every marriage is registered according to the valid laws."[10]

And article 43 (1) (before amendment) said:

"The children born out of wedlock have civil relation to only

their mother and their mother's families." [10]

These articles mean the term of wedlock covers the marriages that are legal according to the Islamic law as well as the positive law that prescribes the registration of the marriages. Therefore, the concept of children born out of wedlock in the Indonesian law consists of two meanings, namely the legitimate and the illegitimate children. The first means the children born from an unregistered marriage that is valid according to Islamic law and the second means the children born from adultery.

The meaning of the children born out of wedlock is reinforced by ICC decree number 46/PUU-VIII/2010. The case was filed to the ICC by Aisyah (Machicha) Mochtar together with his son named Muhammad Iqbal Ramadhan born from her unregistered marriage with Moerdiono. The marriage is actually valid according to Islamic law but invalid to Indonesian law. Based on the provisions of the law number 1/1974, Muhammad Iqbal is the child born out of wedlock. Therefore, he exclusively has a civil relation to his mother and mother's families, not his biological father and the father's families.

According to judges of the ICC, the provisions of the law number $1 / 1974$ concerning the registration of marriage is not against the Indonesian Constitution. The marriage should be registered to guarantee the rights of marriage parties (husband, wife, and child) fulfilled by the state. The marriage is as important as death and birth that should be proved by authentic certificates.

However, regarding the children born out of wedlock, the judges opined that their rights must be satisfied as those were enjoyed by legitimate children. Therefore, according to the ICC judges, the article 43 (1) of the law number $1 / 1974$ should be read "the child born out of wedlock has civil relation to his or her mother and the mother's families and to man as his or her father as long as his or her relation can be proved by scientific and technological evidence that they have blood relation, including his or her father's families."

It is not fair, according to the judges, if the child born out of marriage only has civil relation to his or her mother and his or her mother's families because he/she was born not only from the mother's ovum but from the convergence between mother's ovum and father's spermatozoa. It is an injustice if merely his or her mother who is responsible to give maintenance, protection, loving and caring for her child. The biological father should be also liable to fulfill the rights of the child.

Based on the best interest of the child, it is not fair if he/she has lineage only with his or her mother. The child needs protection, loving and caring given by his or her parents. The child does not request to be born out as a bastard. The child does not behave like a nasty deed, but his or her mother and father do. Therefore, the child 
should have a lineage not only from his or her mother but also his or her father.

In the view of Islamic legal maxims, i.e. "al- ibratu bi 'umum al-lafz la bi khusus al-sabab"[11, p. 269] (the lesson is concluded from the general text, not the special cause). It means that the law to be considered is the general text not the specific cause of the text. Therefore, based on this maxim, the ICC decree concerning the children born out of wedlock covers not only the legitimate children but also the illegitimate ones in the Islamic law. Therefore, their lineage should finally be related to their biological father as long as their paternity can be proved by scientific technology and knowledge, and they should have rights to their father as those of enjoyed by the legitimate children.

Based on the ICC decree, the Indonesian Government should empower and facilitate the women having the children born out of wedlock to sue their rights and their children's rights towards their biological fathers because there are many obstacles to do it. Besides the legal procedure, the obstacles facing the women are social and cultural factors.[12]

\section{B. The Status of Children Born out of Wedlock in Islamic Law}

The concept of children born out of wedlock in Islamic law means the children born out of a valid marriage or without a marriage contract. The children born from such marriage or born from adultery are considered as illegitimate children commonly named bastard (walad al-zina). The lineage of bastard children towards their biological mother is valid and not debatable, but their lineage towards their biological father has triggered heat debate among Muslim jurists.

The orthodox Muslim jurists unanimously opined that the illegitimate children, i.e. the children born from adultery only have lineage towards their mothers. The traditional Muslim jurists from Hanafite, Malikite, Shafi'ite to Hanbalite schools of Islamic law opined that they have no lineage towards their fathers. However, there were dissenting at opinions proposed by al-Hasan and Ibn Sirin that the bastard children had lineage towards their biological fathers who already have been punished while Sulaiman ibn Yasar said that the bastard children had lineage to his father.[13, p. 222]

The unanimous opinion of the majority of Muslim jurists concerning the maternity of the children was based on the clear-cut evidence from pregnancy, birthing to breastfeeding. While the children's paternity to their biological father is hard to be established especially when their mothers take the polygamous relationship to more than one man. Therefore, the main problem of the lineage of the children born out of wedlock to their parents in classical Islamic law was a matter of evidence.

The development of science and technology has affected many parts of Muslim law, including the matter of lineage of the children born out of wedlock (adultery) to their biological father. The Islamic legal maxim said, "alfatwa tataghayyar bi taghayyur al-zaman wa al-makan wa al-ahwal."[14, p. 114] It means that the legal opinion changes as long as the time, place, and condition making up this legal opinion ex Based on the maxim, the jurists or muftis should modify the old legal opinions to meet the contemporary need of justice and the welfare among the people (maslahah).

The matter of lineage in Arab Muslim society that mostly followed patrilineal kinship in time when Islamic law is formulated should adopt the principle of paternity for the lineage of the children. Nevertheless, because of the lack of evidence, the orthodox Muslim jurists have no idea to associate the paternity of the children born out of wedlock (adultery) with their biological father. Therefore, they only associate the children lineage with their mother.

It can be concluded that the lack of evidence is the only reason for classical Muslim jurists to not associate the children born out of wedlock (adultery) with their biological fathers. Therefore, when the test of DNA (deoxyribonucleic acid) was found as a conclusive test of paternity for the bastard children,[15] the legal opinion concerning with the lineage of the bastard children should accommodate the contemporary development of science and technology. When the evidence from pregnancy, birthing, and suckling for maternity are as definitive as DNA test for paternity, the lineage of illegitimate children should be related to not only to their mother but also to their biological father.

\section{The Status of Children Born out of Wedlock Concerning with Inheritance in Maqasid al-Shari'ah Perspective}

Maqasid al-shariah or objectives of sharia, Jasser Auda divides it into three categories, i.e. general maqasid, specific maqasid, and partial maqasid. The g maqasid as the highest maqasid is observed from entire sharia that consists of necessities (daruri) and needs (haji) as well as justice and facilitation. The s maqasid is the objectives of sharia observed from a certain chapter of Islamic law, while partial maqasid is discovered from intents of particular rulings.[16, p. 5]

The general maqasid as the highest maqasid is in line with the statement of Ibn Qayyim al-Jawziyah as follows:

The foundation and basis of sharia are based on wisdom and welfare of people at this world and hereafter. The sharia is all about justice and people's welfare. Every rule deviates from justice to injustice, from mercy to its opposite, from welfare to evil, and from soundness to uselessness are not sharia[17,337].

Further, Auda proposed a system approach to analysis Islamic law that consists of purposefulness, cognition, holism, multi-dimensionality, and openness. [16, p. 192]

To take into account the ruling of the children born out of wedlock, the jurists should regard all opinions of Islamic schools and examine them based on legal sources, linguistic analysis, a method of reasoning, culture and history, location and time. In addition, the jurists should consider rules concerning with illegitimate children as well as other factors pertaining to the children born out of wedlock from rights of the child, psychology, sociology to economy. 
Based on maqasid al-shariah, the ICC decree number 46/PUU-VIII/2010 concerning the children born out of wedlock consists of the legitimate children born from an unregistered marriage and the illegitimate children born from adultery. There are many reasons, first, the legal procedure to determine the paternity of the children of the uncertified marriage should be via legalizing marriage to religious court (ithbat nikah). Therefore, when the judges of ICC order to prove their paternity by means scientific evidence, the decree tends to be given for determining paternity for bastard children born from illegitimate marriage.

Second, Based on the hadith as follows:

"Every infant is naturally born sin-free (fitrah). It is his or her father who proselytizes to him/her (from Islam) into Jew, Christian as well as Magian. It is like an animal bears an animal do you see the mutilated nose in that animal" $[18, \mathrm{p}$. 100]

The hadith means that the children, whether legitimate or illegitimate are born free from any sins offended by others. They should not bear sins made by their parents.

Besides, the Quran said that no one could carry on any burden, someone else perpetrates (Al-An'am: 164; alIsra': 15; Fatir: 18; al-Zumar: 7). There are no children want to be born as a bastard who is morally and socially disdain. It is injustice when wrong and sins are attached to the children who commit nothing. The sin should be shouldered only by their parents for perpetrating adultery that is against the Islamic teachings.

Third, the Quran also says, "Ud'uhum li aba'ihim huwa aqsatu indallah," (al-Ahzab: 5), "Call them (the children under your care) by the name as their fathers. It is more fairness in Allah's sight." It means that the children, whether legitimate or illegitimate as long as their fathers known should be related through their fathers. The Quran prescribes not to call them by the name of their mothers when their fathers were known including by means scientific knowledge.

Islamic law of inheritance stipulates that the blood relationship (nasab) or lineage are one of the causes of inheritance besides affinity or marriage and liberation of a slave (wala'). Heirs by blood relationship consist of two groups namely Quranic and agnatic heirs. The Quranic heirs consist of father, true grandfather, how high so ever, mother, true grandmother how high so ever, daughter, son's daughter how low so ever, full sister, consanguine sister, uterine brother, and uterine sister. The second consists of son, son's son, father, true grandfather how high so ever, full brother, consanguine brother, full brother's son how low so ever, consanguine brother's son how low so ever, full father's brother, consanguine father's brother, son of full father's brother, son of consanguine father's brother, full true grandfather's brother, consanguine true grandfather's brother, son of full true grandfather's brother and son of consanguine true grandfather's brother [19, p. 95].

The heirs by affinity consist of husband and wife, and by emancipation consist of a person who liberates the slave, including the emancipator's heirs ordered as agnatic heirs. The emancipator (mawla mu'tiq) inherits in default of the heirs of blood relationship.
The inheritance rights of the children born out of wedlock that may consist of male and female heirs should regard their position. They can be the heirs of the deceased fathers, grandfathers, uncles, etc. depending upon their positions to the dead. Based on the ICC decree, it can be concluded that the civil relation enjoyed by the children born out of wedlock from their mother is furthermore savored from their biological father as long as their paternity to the fathers was concluded. When the children born out of wedlock have inheritance rights towards their mothers, they also have the rights of inheritance from the fathers.

The children born out of wedlock that consist of two categories in Islamic law, i.e. legitimate and illegitimate children in the view of maqasid al-shariah, their right of inheritance should be granted to them equally because the principle of justice and welfare for the children intends such a provision. They both have rights of inheritance from their mothers as well as biological fathers. As long as their paternity of the legitimate and illegitimate children with the father was concluded, so was their right of inheritance because the lineage (nasab) is one of the causes of inheritance.

Regarding the children born out of wedlock, the Indonesian Civil Code (Burgerlijk Wetboek) (BW) stipulated that they are legitimate children as long as their parents acknowledge them as article 172 said:

Except to the children that has been begotten in adultery or incest, every child that has been begotten not in wedlock, but then the father and mother get married, shall become legitimate, if both parents before they get married has acknowledged him according to the law's regulations, or if such acknowledgment is made in the marriage itself.[20, p. 58]

The children born out of wedlock acknowledged as legitimate children, however, enjoy the share of inheritance smaller than that of the children born in wedlock [21, p. 16]. The BW required the acknowledgment of the parents towards the children born out of wedlock to enjoy their right of inheritance.

The acknowledgment of the parents of the children born out of wedlock in the recent development of technology can be replaced by DNA test, especially the test for the paternity of the children. The DNA test was exerted in the legal development in Nigeria to establish the paternity of the children born out of wedlock and assigned their right of inheritance.[22] The ICC decree number 46/PUU-VIII/2010 also indicated that the paternity of the children born out of wedlock can be concluded by means DNA test in lieu of the acknowledgment of the father provisioned by BW. It can be concluded that based on maqasid al-shariah, the children born out of wedlock, whether the legitimate and illegitimate children have the right to obtain their inheritance from their mothers and fathers as well as their parent's family. 


\section{IV.CONCLUSION}

Based on the discussion, it can be concluded that (1) The Muslim jurists did not associate the lineage of the children born out of wedlock (the children born from adultery) towards their biological fathers because there was no evidence for the association of the lineage in time when the Islamic law being formulated. They only presumed to associate the lineage of the children with the mothers because there was a lot of evidence, for instance, pregnancy, birthing, and breastfeeding. (2) The decree of the ICC number 46/PUU-VIII/2010 consisted of the illegitimate children born from unregistered marriage and the children born from adultery. The children born out of wedlock have the lineage towards their biological mother and father as long as the DNA test proving their paternity. The decree gave the right of inheritance to the legitimate and illegitimate children born out of wedlock because the text of the decree wrote that the children born out of wedlock have civil relation to their mothers and biologic fathers as long as the scientific knowledge proved their paternity. When the civil relation in the text means the right of inheritance, it means that the two categories of the children born out of wedlock have the same right of inheritance towards their biological mothers and fathers as that of enjoyed by the lawful children.

\section{ACKNOWLEDGMENT}

This article cannot be done without Allah's bounty to me, alhamdulillah. I extend my gratitude to many persons, especially the Rector of Universitas Islam Negeri Maulana Malik Ibrahim Malang, Prof. Dr. Abdul Haris, M.Ag., the vice-rectors, I, II, and III namely Dr. M. Zainuddin, MA., Dr. Ilfi Nurdiana, M.Si., and Dr. Isroqunnajah, M.Ag respectively, who patiently supported me to write the scholarly articles on the international level.

Thanks also go to the Director of Postgraduate of the same university, Prof. Dr. Mulyadi, M.Pd., who not only suggested me to internationalize our scholarly knowledge but also back up the expense needed to gain this objective. Last but not least, the appreciation goes to my lovely wife, Khalimatus Sa'diyah and my cute three children, Zaha Sajina Niamilla, Zaha Nadwa Syifa'i Galbina and Hazzam Rocky Althofie respectively, who become an oasis in my academic journey.

\section{REFERENCES}

[1] A. Gheaus, "Children's Vulnerability and Legitimate Authority Over Children," Journal of Applied Philosophy, vol. 35, pp. 60-75, Feb. 2018.

[2] Z. Moody, "The United Nations Declaration of the Rights of the Child (1959): Genesis, transformation, and dissemination of a treaty (re)constituting a transnational cause," PROSPECTS, vol. 45, no. 1, pp. 15-29, Mar. 2015.

[3] P. D. Schulz, "Children Protection, Politics and Procrastination: The Discourse of Deferral," Children Australia, vol. 43, no. 01, pp. 13-22, Mar. 2018.

[4] A. B. Smith, "Child Protection: Policies for Vulnerable Children in New Zealand," in Enhancing Children's Rights, A. B. Smith, Ed. London: Palgrave Macmillan UK, 2015, pp. 111-126.

[5] E. Keddell, "The vulnerable child in neoliberal contexts: the construction of children in the Aotearoa New Zealand child protection reforms," Childhood, vol. 25, no. 1, pp. 93-108, Feb. 2018.

[6] C. Gibson-Davis, "Magic Moment? Maternal Marriage for Children Born Out of Wedlock," Demography, vol. 51, no. 4, pp. 1345-1356, Aug. 2014.

[7] United Nations, Universal Declaration of Human Rights. 1948.

[8] United Nations, Convention on the Rights of the Child. 1989.

[9] B. Bentlage, "Legislating for the Benefit of Children Born Out of Wedlock," Die Welt des Islams, vol. 55, no. 3-4, pp. 378-412, Nov. 2015.

[10] Indonesian Government, Undang-undang Perkawinan (Law of Marriage). 1974.

[11] A. A. B. al-D. M. ibn A. ibn B. Zarkashi al-, al-Bahr alMuhith fi Usul al-Fiqh, vol. 4. n.1.: Dar al-Kutubiy, 1994.

[12] G. Vermeesch, "The Legal Agency of Single Mothers: Lawsuits over Illegitimate Children and the Uses of Legal Aid to the Poor in the Dutch Town of Leiden (1750-1810)," Journal of Social History, vol. 50, no. 1, pp. 51-73, Sep. 2016.

[13] Wuzarah al-Auqaf wa al-Shu'un al-Islamiyyah, alMawsu'ah al-Fiqhiyyah, vol. 45. Kuwait: Wuzarat al-Auqaf wa al-Shu'un al-Islamiyyah, 2006.

[14] I. al-Qayyim Jawziyah al-, I'lam al-Muwaqqi' in 'an Rabb al-Alamin, vol. 6. Riyad: Dar Ibn al-Jawzi, 1423.

[15] S. S. Shah Haneef, "The Status of an Illegitimate Child in Islamic Law: A Critical Analysis of DNA Paternity Test," Global Jurist, vol. 16, no. 2, Jan. 2016.

[16] J. Auda, Maqasid al-Shariah as philosophy of Islamic law: a systems approach. London: The International Inst. of Islamic Thought, 2008.

[17] I. Q. Jawziyah al-, I'lam al-Muwaqqi'in an Rabb al-Alamin, vol. 4. Riyad: Dar Ibn al-Jawzi, 1423.

[18] M. ibn I. A. A. Bukhari al-, Sahih al-Bukhari, vol. 2. n.1.: Dar al-Tawq al-Najah, 1422.

[19] M. M. al-D. 'Abd Hamid al-, Ahkam al-Mawarith fi alShari'ah al-Islamiyyah 'ala Madhahib al-Arba'ah. n.l.: Dar al-Kutub al-Arabiy, 1984.

[20] Indonesia, Ed., Indonesian Civil Code , Kitab UndangUndang Hukum Perdata. Jakarta: Gramedia Pustaka Utama, 2008.

[21] A. Amanat, Membagi warisan berdasarkan pasal-pasal hukum perdata $B W$, Cet. 1. Jakarta: RajaGrafindo Persada, 2000.

[22] M. A. Ajanwachuku, "A Critical Appraisal of the Right of Inheritance of Children Born Out of Wedlock," Hasanuddin Law Review, vol. 1, no. 1, p. 1, May 2016. 